\title{
TOXICOLOGICAL STUDY ON THE HEALTH EFFECTS OF LONG TERM EXPOSURE TO BENZENE IN BENZENE FILLING WORKERS, QASSIM REGION, KSA
}

\author{
Nagy Alfadaly ${ }^{1} .$, Khaled EISayed Aboul-Hagag., ${ }^{2 \& 3}$ Ahmed Al-Robaee., ${ }^{4}$ Hany Al \\ Shobaili., ${ }^{4}$ AbdelLatif Azolibani. ${ }^{4}$ \\ ${ }^{\mathbf{1}}$ Forensic Medicine \& Clinical Toxicology Department, Faculty of Medicine, Qassim \\ University, KSA, ${ }^{2}$ Basic Medical Sciences Department, Pathology \& Forensic Unit, Unaizah \\ Faculty of Medicine and Health Sciences, Qassim University, KSA, \\ dr_ksayed@yahoo.com, ${ }^{3}$ Forensic Medicine \& Clinical Toxicology Department, Faculty of \\ Medicine, Sohag University, Egypt, ${ }^{4}$ Dermatology Department, Faculty of Medicine, Qassim \\ University, KSA
}

\begin{abstract}
Background: Benzene is the smallest and most stable aromatic hydrocarbon, used as an excellent solvent in various industries. Occupational exposure to benzene has been associated with various adverse health effects in humans. Objective: This study was conducted to evaluate the dermatoxic, hematotoxic, hepatoxic and nephrotoxic effects related to long term exposure to benzene in benzene filling workers. Materials and methods: 72 male patients attended at the dermatological clinic, Buraydah central hospital, Qassim region, KSA, seeking medical treatment, over one year (Jumada I 1433 - Jumada I 1434), were included in this study after an informed written consent. They were divided into two groups (GI \& GII): 47 patients who are benzene filling workers in fueling station (GI) and 25 patients who already work in stations as overseers (GII). Full dermatological examination was done for all participants. Blood benzene level was determined by GC mass spectrometry method. Complete blood count (CBC), liver function and kidney function tests were examined. Results: Allergic ((34.04\%) and fungal (19.15\%) diseases were the most common diagnosed problems in GI with high benzene level $(227.83 \pm 10.32 \mathrm{ng} / \mathrm{l})$ in comparison to GII (163.04 $\pm 26.48 \mathrm{ng} / \mathrm{l})$. WBCs count, neutrophil count, monocyte count, lymphocyte count, eosinophil count and basophil count were significantly higher in GI in comparison to GII, $(\mathrm{p}<0.05)$. No significant differences were noticed in $\mathrm{Hb}, \mathrm{RBCs}$ and platelets between the two groups, $(\mathrm{p}>0.05)$. The mean value of (ALT) $(65.12 \pm 14.3)$ and (AST) $(63.25 \pm 15.1)$ in GI was significantly increased ( $\mathrm{p}=0.046$ and $\mathrm{p}=0.035$ respectively) than the corresponding values in GII (41.40 \pm 13.11 and $40.23 \pm 16.5$ respectively). No significant differences were obtained in urea and creatinine levels between the two groups. Conclusion: This study suggests that long term benzene exposure causes dermatotoxic effects that enhance incidence of skin diseases. Blood disorder and liver involvement in these workers are possible and full attention should be given in medical surveillance of benzene workers.
\end{abstract}

Key words: Benzene, dermatotoxicity, $\mathrm{CBC}$, liver function, kidney function

\section{INTRODUCTION}

Benzene is the smallest and most stable aromatic hydrocarbon (Blocsak \& Nerland, 1983). It is used as an excellent solvent in various industries including dyes, varnish, lacquer, leather and so on (Khan, 2007). It is a ubiquitous industrial solvent and 
widely distributed environmental contaminant that has been linked to adverse health effect in humans and animals (Yardley et al., 1991; Simon et al., 1997; Nazia et al., 2008). Although inhalation exposure is the primary route for benzene exposure (Rinsky et al., 1981), the skin is considered a portal of entry for benzene. It penetrates normal intact human skin more rapidly than many small organic molecules, and is potentially toxic to the skin (Blank and MCAuliffe, 1985; ASTDR, 2012). Benzene is metabolized, primarily in the liver, to a variety of hydroxylated and ring-opened products that are transported to the bone marrow where subsequent secondary metabolism occurs (Snyder and Hedli, 1996). Occupational exposure to benzene has been associated with various health problems in humans (Subrahmanyam et al., 1991). The international agency for research on cancer classified benzene as a group I human carcinogen (IARC, 1987). The limit of exposure to benzene has decreased over time from $100 \mathrm{ppm}$ in 1946 to $10 \mathrm{ppm}$ in 1997 and $0.5 \mathrm{ppm}$ in 1998 by the American Conference of Governmental Industrial (Liu et al. 2000).

Exposure to low levels of benzene vapors may cause dermatitis. Highly concentrated benzene vapors or spills of liquid benzene on the skin can cause second degree burns. Repeated or prolonged skin contact with liquid benzene can degrease the skin, hence cracking and peeling of the skin (John, 2013). Hemotoxicity is the most noted and characteristic systemic effect resulting from intermediate and chronic benzene exposure leading to aplastic anemia, leucopenia and thrombocytopenia (Abernethy et al.,
2004). Benzene is liver and kidney toxicants, known or suspected carcinogens, and capable of damaging the reproductive and central nervous system (Adeyemi et al., 2009). Benzene could be detected from blood and urine by headspace Solid-Phase Microextration/Gas-Chromatography

(Paulo et al., 2010); other methods have been developed for the determination of solvents in blood and/or urine (Asakawa et al., 1999; Schimming et al., 1999; Alegretti et al., 2004). The exact role of topical exposure to benzene and its hazards profile remains incompletely defined (Modjtahedi et al., 2008).

\section{AIM OF THE WORK:}

The aim of the present study is to evaluate the dermatoxic, hematotoxic, hepatotoxic and nephrotoxic effects related to long-term exposure to benzene in benzene filling workers.

\section{Subjects and methods:}

\section{Study population}

This study was conducted on 72 male patients attended at the dermatological clinic, Buraydah central hospital, Qassim, KSA, seeking medical treatment, over one year (Jumada I 1433 - Jumada I 1434). Cross sectional design was used for conducting this study. The patients were divided into two groups (GI \& GII): 47 patients who are benzene filling workers in fueling station (GI) and 25 patients who already work in stations as overseers (GII). Full dermatological examination was done for all participants. Blood samples were obtained from the participants for determination of benzene level in the blood and evaluate hematological, liver function and kidney function changes. Smokers and subjects suffering from 
any chronic illness were excluded from the study. Written informed consent was obtained from each subject prior to the study.

\section{Treatment and storage of blood} samples

Venous blood samples $(10 \mathrm{ml}$.) each were taken with disposable syringes and placed in glass tubes containing two drops of $10 \%$ ethylene diamine tetra-acetic acid (EDTA) solution. The glass tube, filled to capacity in order to avoid any residual air bubbles between the blood surface and the tube cap, then closed with a pierceable screw-on cap fitted with a Teflon rubber ring seal. After a short shacking to enhance the anticoagulant effect of EDTA, the blood samples were stored at $4^{\mathrm{O}} \mathrm{C}$ until use. Benzene in blood was assayed by the headspace technique combined with gas chromatography with a mass spectrometer detector method previously described by Perbellini, et al., 2002. Hematologic analysis was performed with an autoanalyzer, SYSMEX SF-3000 (TOA Medical Electronics Co., Japan). The measured items were hemoglobin, red blood cell (RBC) count, white blood cell (WBC) count, neutrophils, lymphocytes, monocytes and platelet count. Serum concentrations of total protein, albumin, total bilirubin, Alanine Aminotransferase (ALT), aspartate aminotransferase (AST), urea and creatinine levels were determined using Beckman's autoanalyser.

\section{Gas spectrometry for benzene determination}

Benzene and methanol (laboratory grade purity) were purchased from Carlo Erba (Milan, Italy). Benzene- $\mathrm{d}_{6}$ (> 99.96 atom \% D) was obtained from
Sigma-Aldrich (Milan Italy).

A Stock solution of benzene 200 $\mathrm{mg} / \mathrm{l}$ in methanol was prepared. The internal standard solution containing deuterated benzene in water $(50 \mathrm{mg} / \mathrm{l})$ was prepared by diluting a methanol solution of $100 \mathrm{mg} / 1$ in water. Blood from non-smoking, non-occupationally exposed donors were used for calibration. Eight blood calibration samples (5ml for each) spiked with 0 , $15,30,60,120,240,480$ and $960 \mathrm{ng} / \mathrm{l}$ of benzene, prepared from the stock solution, were used. A volume of $30 \mu 1$ of the internal standard solution obtained was added to each blood sample.

A headspace auto-sampler using a loop volume of $1 \mathrm{ml}$ was used. Chromatographic separation was performed in gas-chromatograph with an HP 7694E headspace autosampler (Hewlett-Packard), connected via a volatile interface configured in the direct injection mode. An HP 6890 gas chromatograph (Hewlett-Pac kard), interfaced with the HP 5973 mass detector operating in the electron impact (EI) mode was used. The gas chromatograph was equipped with a hybrid column: PoraPLOT Q $(5 \mathrm{~m}$ length, $0.32 \mathrm{~mm}$ I.D., $10 \mathrm{~mm}$ film thickness, Chrompack) connected to an HP-5MS (30 m length, $0.25 \mathrm{~mm}$ I.D., $0.25 \mathrm{~mm}$ film thickness, HewlettPackard).

Blood samples were heated at $50^{\circ} \mathrm{C}$ and shaken for $60 \mathrm{~min}$ in the autosampler before the headspace was withdrawn: The loop and transfer line temperatures were both $110^{\circ} \mathrm{C}$. The transfer line was connected to the gaschromatograph via a volatile interface heated at $120^{\circ} \mathrm{C}$. The oven temperature of the gas-chromatograph was kept at $100^{\circ} \mathrm{C}$ during the injection $(1 \mathrm{~min})$. 
The temperature was then increased to $210^{\circ} \mathrm{C}$ at a rate of $20^{\circ} \mathrm{C} / \mathrm{min}$ and this temperature was maintained for $4 \mathrm{~min}$. Helium was used as the carrier at 2.2 $\mathrm{ml} / \mathrm{min}$ constant flow.

The mass detector, with the source kept at $250^{\circ} \mathrm{C}$ operated in electron impact mode with the selected ion monitoring mode. The solvent delay time was $3 \mathrm{~min}$, and the dwell time 50 ms.. The masses detected were $\mathrm{m} / \mathrm{z} 78$ for benzene. Benzene- $d_{6}$ as internal standard was monitored with $\mathrm{m} / \mathrm{z} 84$. The mass recorded for each compound were used to check the isotopic ratio; their quantification was based on the peak areas of the following masses: 78 for benzene, 84 for benzene- $\mathrm{d}_{6}$.

Approximate retention times were as follows: Benzene $6.02 \mathrm{~min}$, benzene$\mathrm{d}_{6} 6.05 \mathrm{~min}$. Quantification was not based on the ratio of the chromatographic peak area of the analyte to the internal standard because the addition of a very small amount of internal standard gives rise to minor errors. These make for a slightly worse correlation coefficient of the regression lines as compared to data not corrected for the internal standard. When data were processed without the ratio to the internal standard, the calibration curves showed correlation coefficients ranging from 0.9994 to 0.9999 , while the data calculated using the internal standard yielded coefficients ranging from 0.9976 to 0.9994 . The internal standard was used to check that the individual injections were good enough, with no problems of injection needle or carrier flow. The lower limit of detection for benzene was $16 \mathrm{ng} / \mathrm{l}$.

\section{Statistical analysis}

Data were computed and analyzed using SPSS (Statistical Package of Social Sciences) version 9.0. The data were expressed as frequencies and mean \pm SD. Chi square test was used to compare non-parametric data, T-test and Correlation were used to compare the parametric data. $\mathrm{P}$ value was considered significant at level $<0.05$.

\section{RESULTS}

The mean age and mean work period of the study groups (GI) and (GII) are shown in table 1; there was no significant statistical difference between the mean age and work period of the two groups. Dermatological evaluation of the participants revealed that most of the dermatological diseases reported in higher percentage in GI than GII but no significant statistical differences were obtained, $p$ $>0.05$, (table 2). Allergic and fungal diseases were the most common diagnosed problems in the patients. Allergic diseases were reported in 16 patients $(34.04 \%)$ of GI in comparison to 3 patients $(12.0 \%)$ in GII with a significant statistical difference between GI and GII ( $p=0.0002)$. Fungal diseases reported in 9 patients $(19.15 \%)$ in GI in comparison to 4 patients $(16.0 \%)$ with no significant statistical difference between the two groups $(p=0.577)$. The mean blood benzene level was elevated in GI $(227.83 \pm 10.32 \mathrm{ng} / \mathrm{l})$ than GII (163.04 \pm $26.48 \mathrm{ng} / \mathrm{l})$ and there was a significant statistical difference between the two groups, $\mathrm{p}<0.05$, (table 3).

The results of comparison of $\mathrm{CBC}$ are shown in table 4. The WBCs count, neutrophil count, monocyte count, lymphocyte count, eosinophil count and basophil count were significantly higher in benzene filling workers (GI) in comparison to the overseers (GII), ( $p$ $<0.05)$. No significant differences were noticed in $\mathrm{Hb}, \mathrm{RBCs}$ and platelets 
between the two groups, $p>0.05$. The correlation between CBC parameters and blood benzene level are weak and summarized in table 5. Blood benzene level negatively correlated with $\mathrm{Hb}$, $\mathrm{RBcs}$ and platelets but positively and significantly correlated with WBCs count $(r=0.09, p=0.028)$, figure 1 .

Table 6 shows the mean \pm SD levels of total protein, albumin, total bilirubin, ALT, AST, prothrombine concentration, urea and creatinine in GI with corresponding value in GII. The mean value of ALT $(65.12 \pm 14.3)$ and AST (63.25 \pm 15.1$)$ in GI was significantly increased $(\mathrm{p}=0.025$ and $\mathrm{p}=0.032$ respectively) than the corresponding values in GII (41.40 \pm 13.11 and $40.23 \pm 16.5$ respectively). The total protein level increased within the normal range in GI $(7.85 \pm 2.65)$ than GII (7.37 \pm 3.59$)$, whereas albumin level decreased to $5.10 \pm 0.32$ in GI in comparison with GII $(5.25 \pm 0.21)$. Mean \pm SD values of total protein, Albumin, total bilirubin, urea and creatinine levels were not significantly different between the two groups $(\mathrm{p}=$ $0.673,0.856,0.972,0.377$ and 0.627 respectively) but prothrombine concentration was significantly different $(\mathrm{p}=0.026)$. The correlation between liver \& kidney parameters and blood benzene level are weak and summarized in table 7. Blood benzene level negatively correlated with total protein, albumin and total bilirubin but positively and significantly correlated with ALT and AST levels $(\mathrm{r}=0.105, \mathrm{p}$ $=0.033 ; \mathrm{r}=0.110, \mathrm{p}=0.021)$, figures

$2 \& 3$.

Table (1): Mean age and mean occupation period in the studied groups

\begin{tabular}{|l|c|c|c|}
\hline \multicolumn{1}{|c|}{ Group } & $\begin{array}{c}\text { GI (Benzene filling } \\
\text { workers }) \\
(\mathbf{n}=47)\end{array}$ & $\begin{array}{c}\text { GII (Overseers) } \\
(\mathrm{n}=\mathbf{2 5})\end{array}$ & P value \\
\hline $\begin{array}{c}\text { Parameter } \\
\text { Age (year) mean } \pm \text { SD }\end{array}$ & $\mathbf{3 1 . 2 3} \pm 9.66$ & $31.40 \pm 9.19$ & $\mathbf{0 . 9 4 4}$ \\
\hline $\begin{array}{c}\text { Work period(year) } \\
\text { mean } \pm \text { SD }\end{array}$ & $9.70 \pm 8.53$ & $8.52 \pm 8.01$ & 0.956 \\
\hline
\end{tabular}

Table (2): Dermatological health effects in the studied groups

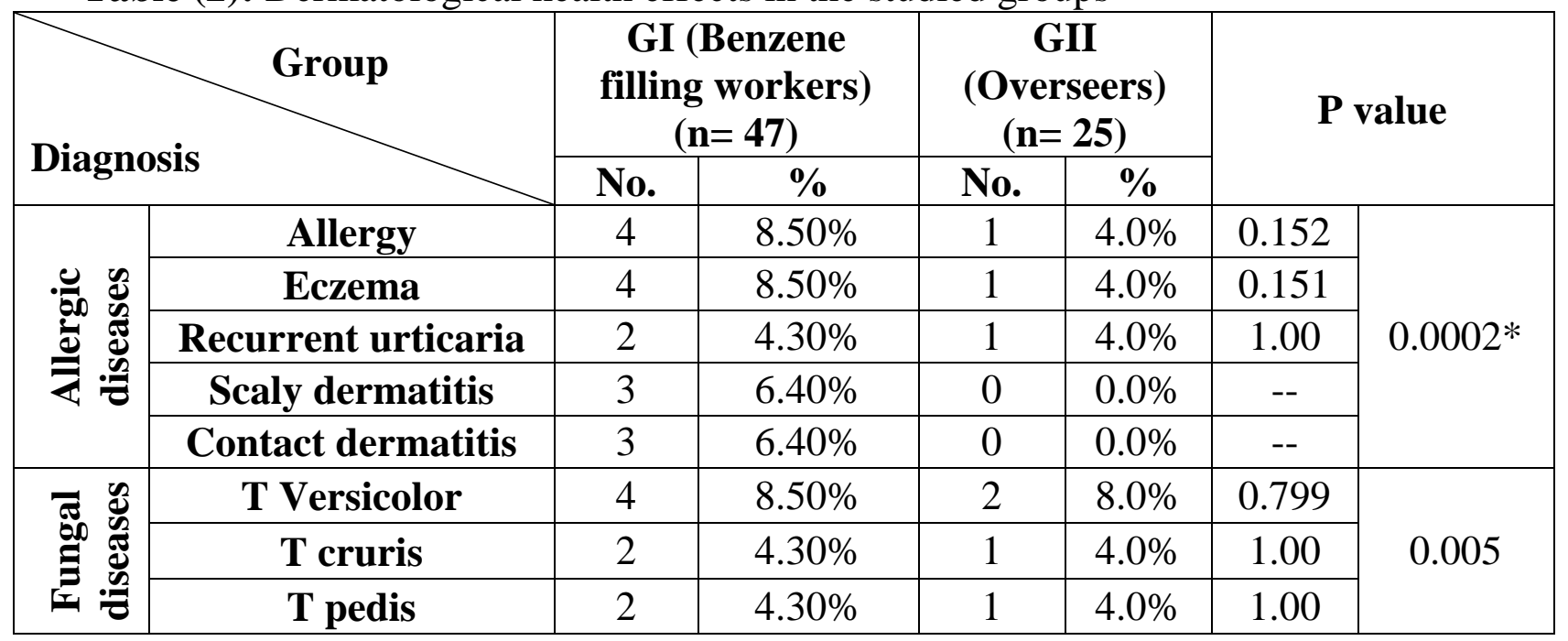




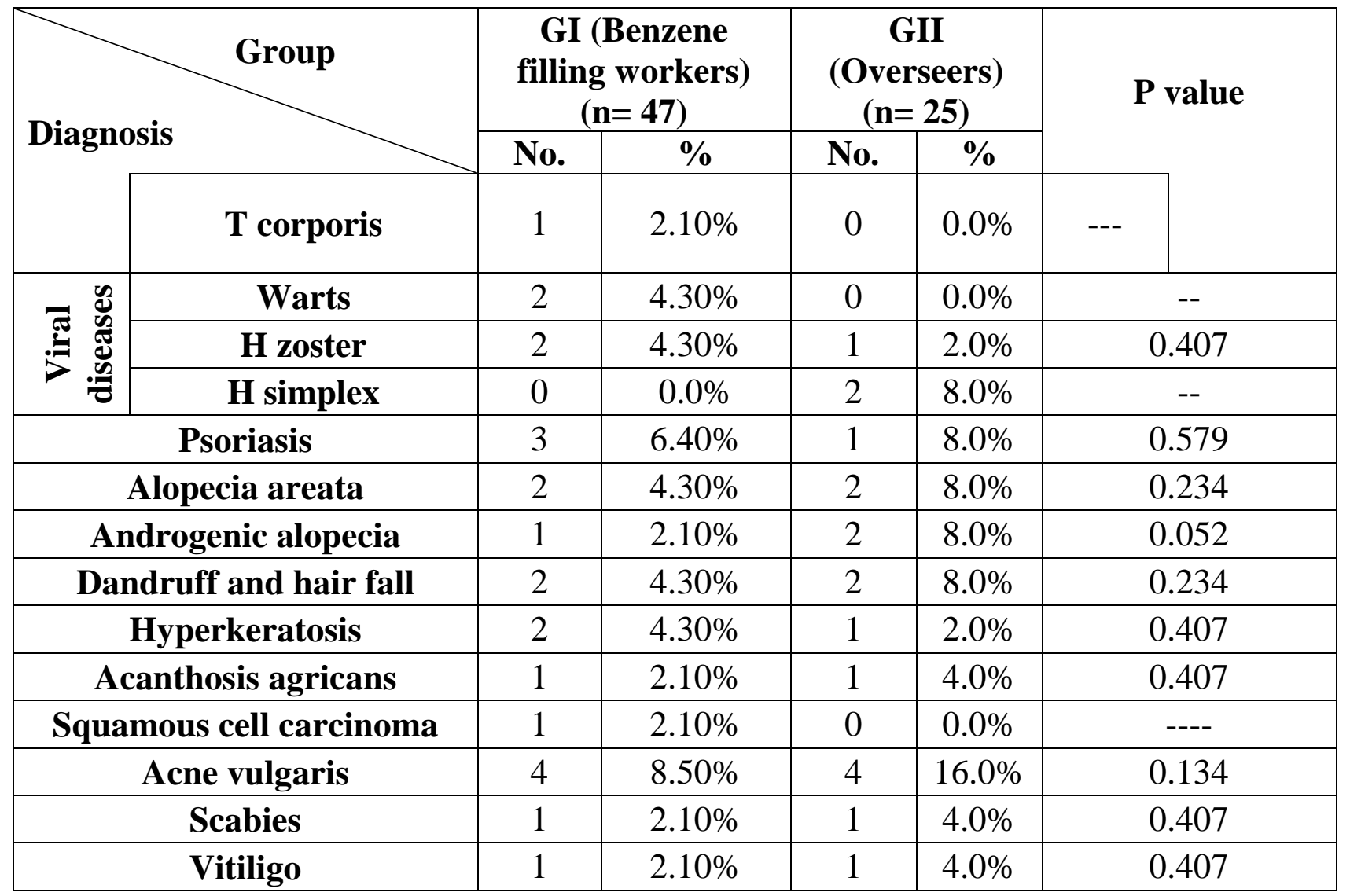

* Significant $\mathrm{p}<0.05$

Table (3): Mean blood benzene level in the studied groups

\begin{tabular}{|c|c|c|}
\hline \multirow{2}{*}{ Parameter } & Penzene level & \multirow{2}{*}{ P value } \\
\cline { 2 - 2 } & $\begin{array}{c}\text { Mean } \pm \text { SD } \\
(\mathbf{n g} / \mathbf{l})\end{array}$ & \multirow{2}{*}{$\mathbf{0 . 0 0 0 1 *}$} \\
\hline $\begin{array}{c}\text { GI (Benzene filling worker }) \\
(\mathbf{n}=47)\end{array}$ & $\mathbf{2 2 7 . 8 3} \pm 10.32$ & \\
\hline $\begin{array}{c}\text { GII (Overseers) } \\
(\mathbf{n}=25)\end{array}$ & $\mathbf{1 6 3 . 0 4} \pm \mathbf{2 6 . 4 8}$ & \\
\hline
\end{tabular}

* Significant $\mathrm{p}<0.05$

Table (4): Comparison of CBC count between GI \& GII

\begin{tabular}{|c|c|c|c|}
\hline Variable & $\begin{array}{l}\text { GI (Benzene filling workers ) } \\
(n=47)\end{array}$ & $\begin{array}{c}\text { GII (overseers) } \\
(\mathbf{n}=\mathbf{2 5})\end{array}$ & $P$ value \\
\hline $\mathrm{Hb}(\mathrm{gm} / \mathrm{dl})$ & $15.47 \pm 1.21$ & $15.43 \pm 1.32$ & 0.902 \\
\hline RBCs (x 10 $/ \mu \mathrm{l})$ & $5.67 \pm 0.378$ & $5.66 \pm 0.388$ & 0.896 \\
\hline Platelets $\left(x 1^{3} / \mu \mathrm{l}\right)$ & $305.72 \pm 64.05$ & $301.26 \pm 61.57$ & 0.774 \\
\hline WBCs $\left(\times 10^{3} / \mu \mathrm{l}\right)$ & $6.47 \pm 0.625$ & $6.13 \pm 0.755$ & $0.046^{*}$ \\
\hline - Neutrophil & $3410.7 \pm 1085.5$ & $3347.2 \pm 9235.3$ & $0.03 *$ \\
\hline - Lymphocyte & $2200.6 \pm 5328.7$ & $2076.9 \pm 4546.1$ & $0.026^{*}$ \\
\hline - Monocyte & $652.5 \pm 215.4$ & $542.8 \pm 132.6$ & $0.001 * *$ \\
\hline - Eosinophil & $167.7 \pm 230.9$ & $124.2 \pm 183.2$ & $0.024^{*}$ \\
\hline - Basophil & $41.1 \pm 20.3$ & $43.3 \pm 19.1$ & $0.032 *$ \\
\hline
\end{tabular}


* Significant $\mathrm{p}<0.05$

** Highly significant $\mathrm{p}<\mathbf{0 . 0 0 5}$

Table (5): The correlation between CBC parameters and blood benzene level in the studied groups

\begin{tabular}{|l|c|c|}
\hline Parametes & r & P value \\
\hline Hb $(\mathbf{g m} / \mathbf{d l})$ & -0.18 & 0.092 \\
\hline RBCs $(\mathbf{x ~ 1 0} / \boldsymbol{\mu l})$ & -0.15 & $0.046^{*}$ \\
\hline Platelets $(\mathbf{x ~ 1 0} / \boldsymbol{\mu l})$ & -0.08 & 0.08 \\
\hline WBCs $(\mathbf{x ~ 1 0} / \boldsymbol{\mu l})$ & 0.09 & $0.028^{*}$ \\
\hline$\bullet \quad$ Neutrophil & 0.05 & 0.056 \\
\hline$\bullet \quad$ Lymphocyte & 0.04 & 0.083 \\
\hline$\bullet$ Monocyte & 0.02 & 0.122 \\
\hline$\bullet$ Eosinophil & 0.01 & 0.072 \\
\hline$\bullet$ Basophil & 0.02 & 0.212 \\
\hline
\end{tabular}

* Significant $\mathbf{p}<0.05$

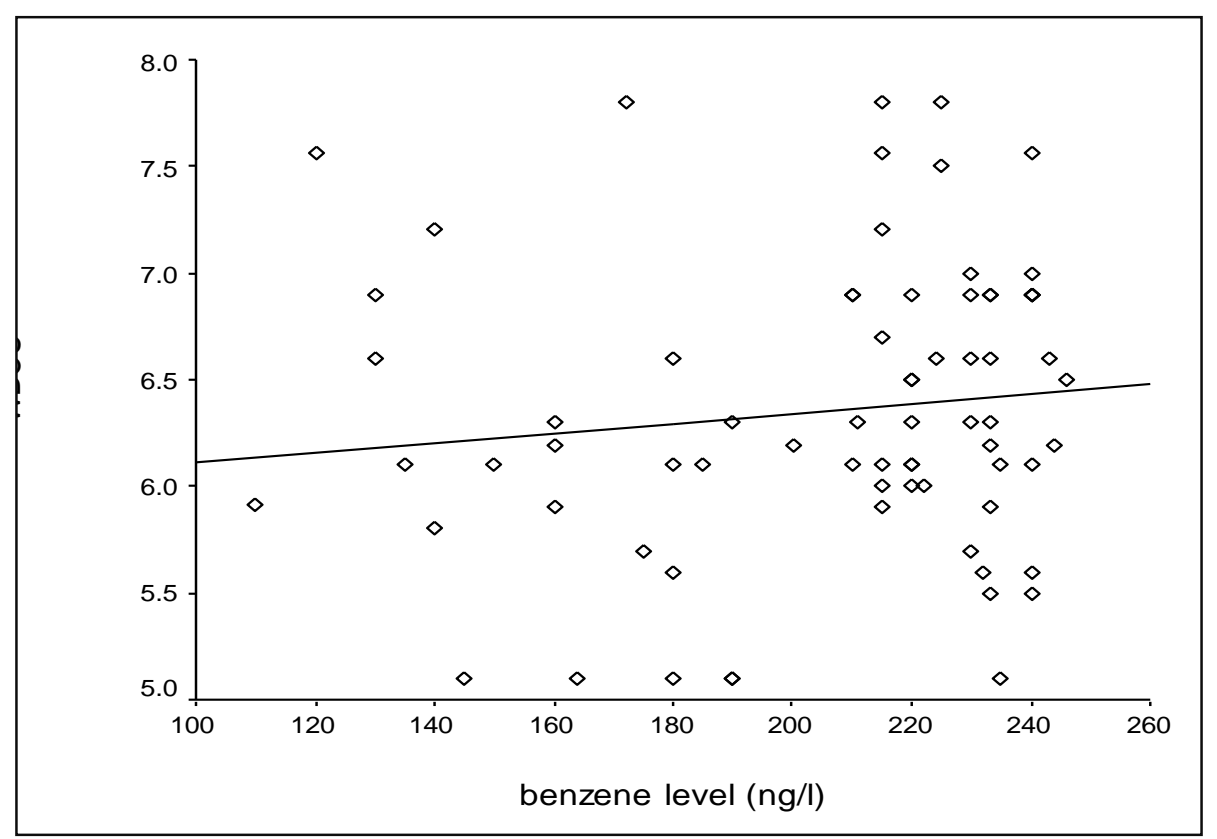

Figure (1): Correlation between benzene level and WBCs count

Table (6): liver and kidney function of GI \& GII in the studied groups

\begin{tabular}{|l|c|c|c|}
\hline Variable & $\begin{array}{c}\text { GI (Benzene filling worker ) } \\
(\mathbf{n = 4 7 )}\end{array}$ & $\begin{array}{c}\text { GII (Overseers) } \\
(\mathbf{n = 2 5})\end{array}$ & P value \\
\hline Total protein (gm/dl) & $7.85 \pm 2.65$ & $7.37 \pm 3.59$ & 0.673 \\
\hline Albumin (gm/dl) & $5.32 \pm 1.21$ & $5.57 \pm 1.60$ & 0.856 \\
\hline Total bilirubin (mg/dl) & $0.5915 \pm 0.2376$ & $0.5920 \pm 0.2482$ & 0.972 \\
\hline ALT (U/l) & $65.12 \pm 14.3$ & $41.40 \pm 13.11$ & $0.025^{*}$ \\
\hline AST (U/I) & $63.25 \pm 15.1$ & $40.23 \pm 16.5$ & $0.032^{*}$ \\
\hline $\begin{array}{l}\text { Prothrombin } \\
\text { concentration (\%) }\end{array}$ & $87.24 \pm 12.03$ & $87.59 \pm 14.39$ & $0.026^{*}$ \\
\hline Urea (mg/dl) & $23.45 \pm 6.96$ & $21.96 \pm 6.67$ & 0.377 \\
\hline
\end{tabular}




\section{Creatinine (mg/dl)}

* Significant $\mathrm{p}<0.05$

Table (7): The correlation between liver and kidney function parameters and blood benzene level in the studied groups

\begin{tabular}{|l|c|c|}
\hline Parameters & R & P value \\
\hline Total protein $(\mathbf{g m} / \mathbf{d l})$ & -0.14 & 0.102 \\
\hline Albumin $(\mathbf{g m} / \mathbf{d l})$ & -0.11 & 0.056 \\
\hline Total bilirubin $\mathbf{( m g / d l )}$ & -0.05 & 0.245 \\
\hline ALT (U/) & 0.105 & $0.033^{*}$ \\
\hline AST (U/l) & 0.110 & $0.021^{*}$ \\
\hline $\begin{array}{l}\text { Prothrombin } \\
\text { concentration (\%) }\end{array}$ & 0.01 & 0.431 \\
\hline Urea (mg/dl) & 0.01 & 0.526 \\
\hline Creatinine (mg/dl) & 0.01 & 0.611 \\
\hline
\end{tabular}

* Significant $\mathbf{p}<0.05$

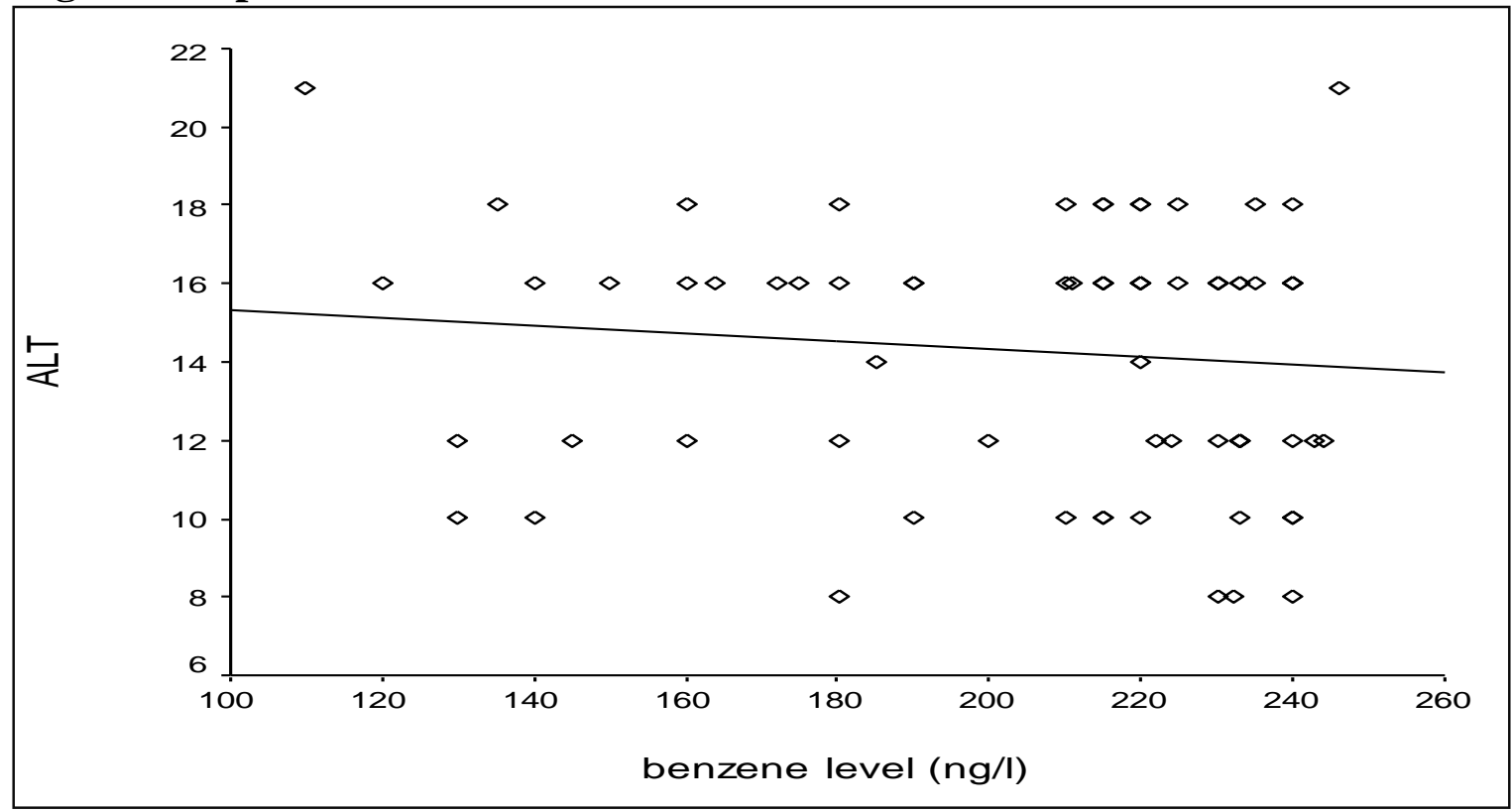

Figure (2): correlation between benzene level and ALT level 


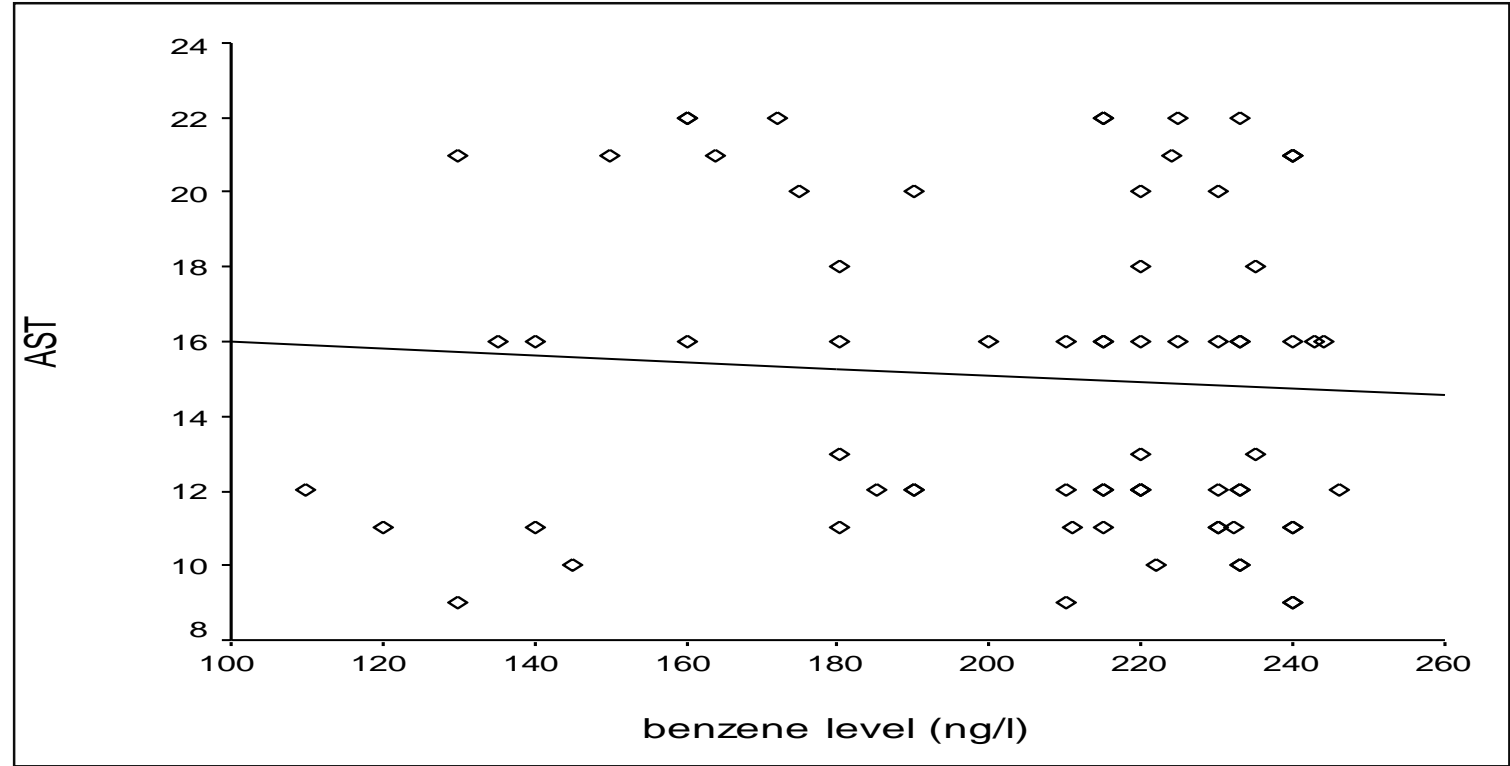

Figure (3): correlation between benzene level and AST level

\section{DISCUSSION}

This study was conducted to evaluate the dermatoxic, hematotoxic, hepatoxic and nephrotoxic effects related to long term exposure to benzene in benzene filling workers. An appreciation of the dangers posed by benzene exposure is vital to hazard assessment. While the respiratory route of exposure remains the most common and well studied path of contact, the possibility remains that topical exposure to benzene may have relevant consequences (Schimming et al., 1999).

In the present work, allergic skin diseases were the most common skin problem. The increased percent of allergic diseases in the benzene filling workers can be explained by the effect of benzene exposure on elicitation of both types of allergy (local eczema) or general allergy in patients exposed to benzene for a long time. Reports indicated that while benzene is absorbed through the skin and prolonged or excessive contact may cause signs consistent with the defatting (delipidising) effects of organic solvents such as erythema, vesiculation and dermatitis (Henderson, 2001). In a recent study carried out on a number of children with atopic dermatitis in a public child day care center, a strong correlation was found between severity of dermatitis and exposure to environmental factors including benzene (Eun-Hye et al., 2011). In addition, skin problems might be resulting from exposure of the benzene station workers to the inorganic lead (Cabaravdic et al., 2010). Benzene on its own has been shown to produce several types of neoplasms in experimental animals. These include various types of epithelial neoplasms and a few lymphomas and leukemias (IPCS, 1993).

The present study showed that fungal diseases were reported in higher rates in benzene filling workers (GI) than overseers (GII). This can be explained by that repeated or prolonged skin contact with liquid benzene can degrease the skin, hence cracking and peeling of the skin Adeyemi et al., (2009), with impaired the immune system in workers exposed to benzene (Brandao et al., 2005), which may contribute to invasion by fungi and 
microorganisms.

In the present study both benzene filling workers and overseers have benzene in their blood with higher level in benzene filling workers than the overseers. The results obtained can be explained by that benzene workers are exposed to benzene by inhalation and percutaenous absorption of benzene that established in many studies Adeyemi et al., (2009); Blank and MCAuliffe, (1985), while the overseers group were exposed to inhalation of environmental benzene pollution in the workplace.

The hematpoietic system has been shown to be a major target site in long term benzene exposure. It has been well documented that relatively high levels of benzene exposure can cause decrease in WBCs count, RBCs count, Hb levels and platelets count in human and mice (Cody et al., 1993; Plappert et al., 1994; Rothman et al., 1996).

In the present study, WBCs count, neutrophil count, monocyte count, lymphocyte count, eosinophil count and basophil count were significantly higher in benzene filling workers in comparison to the overseers group. These results are in agreement with that of Liu et al., 2000 who reported WBCs count, neutrophil count, monocyte count, lymphocyte count, eosinophil count were higher in long term benzene exposure. Townsend et al., 1978 and Ward et al., 1996 found hematological suppression effects after low level benzene exposure. Khuder et al., 1999 found that with the exception WBCs, all other CBC values were significantly reduced. Whereas, Tsai et al, 1983 and Hancock et al., 1984 reported no differences in RBCs count, WBCs count, $\mathrm{Hb}$ level or platelets count after low level benzene exposure. Collins et al., 1991 \& 1997 Concluded that low level benzene exposure didn't appear to result in abnormal $\mathrm{CBC}$ results. The difference in the results between this study and others studies is due to different exposure period, study design and blood parameters measured. As well as the genetic susceptibility that established to play a role in benzene toxicity (Lan et al., 2004).

The biochemical indices monitored in the liver and kidneys are useful 'markers' for assessment of tissue damage. The measurement of activities of various enzymes in the tissues and body fluids plays a significant role in disease investigation and diagnosis (Malomo, 2000), assault on the organs/tissues and to a reasonable extent the toxicity of the drug (Yakubu et al., 2003). Tissue enzymes can also indicate tissue cellular damage caused by chemical compounds long before structural damage that can be picked by conventional histological techniques (Yakubu et al., 2009).

Hepatic damage induced by any toxins can be observed by evaluating serum TP, AST, ALP and ALT levels. As these enzymes are cytoplasmic in nature, upon liver injury, these enzymes enter into the circulatory system due to altered permeability of cell membrane. During inflammatory conditions and acute liver damage, ALT and AST rise dramatically Nazia et al., 2012. The present study reports significant increase in ALT and AST levels that may be due to inflammatory conditions in GI. The statistically significant changes in the levels of ALT and AST in GI than GII indicate changes in the liver function which may be due to inflammation, illustrating that as the concentration of benzene increases, inflammation as well as the toxicity increases. The liver produces most of 
the plasma proteins in the body and albumin is a protein made specifically by the liver. Albumin is decreased in chronic liver disease, nephritic syndrome, a state of poor nutrition and during protein catabolism. Total protein and albumine were slightly raised within the normal range in the two groups, thus revealing that they are not having any of the above diseases. These results are in agreement with that of Nazia et al., 2012 and Adeyemi et al., 2009.

\section{CONCLUSION \& RECOMMENDATIONS}

The results obtained from the present study indicate that long-term benzene exposure causes dermatotoxic effects that enhance incidence of skin diseases. Blood disorder and liver involvement in these workers is possible and full attention should be given in medical surveillance of benzene workers.

It is to be recommended that personal protective equipments should be used at the work environment of benzene such as gloves, safety goggles, safety shoes, protective clothing, and respirators aiming at reducing the exposure as much as possible. Also, benzene workers should be subjected to periodic medical examination for the onset of any symptoms or signs affecting the skin, blood or body organs that result from prolonged exposure to benzene.

\section{REFERENCES}

Abernethy D J, Elena VK, Jason RL., (2004): Human CD34 hematopoietic progenitor cells are sensitive targets for toxicity induced by 1,4-Benzoquinone. Toxicol Sci; 79: $82-89$.
Adeyemi O, Ajayi J O, Olajuyin A M, Oloyede O B, Oladiji AT, Oluba O M, Adeyemi O, Ololade I A, Adebayo E A., (2009): Toxicological evaluation of the effect of water contaminated with lead, phenol and benzene on liver, kidney and colon of Albino rats. Food and Chemical Toxicology; 47: 885-887.

Alegretti, A. P.; Thiesen, F. V.; Maciel, G. P., (2004): Analytical method for evaluation of exposure to benzene, toluene, xylene in blood by gas chromatography preceded by solid phase microextraction. $\mathbf{J}$ Chromatogr B Analyt Technol Biomed Life Sci. 25;809(1):183187.

Asakawa F., Jitsunari F., Choi J., Suna S., Takeda N., Kitamado T., (1999): Method for Analyzing Urinary Toluene and Xylene by Solid-Phase Microextraction (SPME), and Its Application to Workers Using Organic Solvents. Bull. Environ. Contam. Toxicol.; 62, 109-116

ASTDR, Agency for Toxic Substances and Disease Registry (2012): Benzene. Available at www.atsdr.cdc.gov/mhmi $/ \mathrm{mmg} 3 . p d$ f. Accessed at 19/11/2012.

Blank I. H. and MCAuliffe D. J., (1985): Penetration of benzene through human skin. The journal of investigative dermatology; 85: 522526.

Blocsak L. E., Nerland, D. E., (1983): Inhibition of erythropoiesis by benzene and benzene metabolites. Toxicol. Appl. Pharmaco ; 69: 363368.

Brandao M. M., Rego M. A., Pugliese L., Clar^encio J., Bastos C. M., Ferreira J., Meyere R., Nevesd 
M., Freire S. M., (2005): Phenotype analysis of lymphocytes of workers with chronic benzene poisoning. Immunology Letters; 101: 65-70.

Cabaravdic M., Mijanovic M., Kusturica J., Cabaravdic A., (2010): Occupational exposure of workers at gas station to inorganic lead. Med Arh; 64(2):107-109.

Cody R. P., Strawderman W. W., Kipen H. M., (1993): Hematologic effects of benzene. Job-specific trends during the first year of employment among a cohort of benzene exposed rubber workers. J Occup Med; 35: 776-782.

Collins J. J., Conner P., Friedlander B. R., Easterday P. A., Nair R. S., Braun J., (1991): A study of the hematologic effects of chronic low level exposure of benzene. J Ocupp Med; 33: 619-626.

Collins J. J., Ireland B. K., Easterday P. A., Nair R. S., Braun J., (1997): Evaluation of lymphopenia among workers with low level benzene exposure and utility of routine data collection. J Occup Environ Med; 39: 232-237.

Eun-Hye K., Soyeon K., Hae-Kwan C., Jung H. L., Mun-Joo B., Kyoboong K., Kwon J., Kang M. A., Sang I., (2011): Symptom Severity of Atopic Dermatitis and Indoor Exposure to Air Pollutants in a Child Day Care Center. Epidemiology; 22(1): S208.

Hancock D. G., Moffitt A. E., Hay E. B., (1984): Hematological findings among workers exposed to benzene at a coke oven by-product recovery facility. Arch Environ Health; 39: 414-418.

Henderson, F. R., (2001): Aromatic hydrocarbons, benzene and other alkyl benzenes. Patty's Industrial Hygiene and Toxicology; 4: 231301.

IARC, International agency for research on cancer (1987): Benzene. In: international agency for research on cancer monographs on the evaluation carcinogenic risks to man. An updating of IARC Monographs. IARC, Lyon, France; 42(7): $93-148$.

IPCS, International Program on Chemical safety (1993): Environmental Health Criteria 150. Benzene. WHO, ISBN 924 1571500 .

John T., (2013): harmful effects of benzene.

www.livestrong.com/article/10189

2-harmful-effects-benzene/. Accessed at 19/01/2013.

Khan H. A., (2007): Benzene's toxicity: a consolidated short review of human and animal studies. Human \& Experimental Toxicology; 26(9):677-85.

Khuder S. A., Youngdale M. C., Bisesi M. S. Schaub E. A., (1999): Assessment of complete blood count variations among workers exposed to low levels of benzene. $\mathrm{J}$ Occup Environ Med; 41: 821-826.

Lan Q., Zhang L., Li G., Vermeulen R., Weinberg R. S., Dosemeci M., Rappaport S., Shen M., Alter B. P., Wu Y., Kopp W., Waidyanatha S., Rabkin C., Guo W., Chanock S., Hayes R. B., Linet M., Kim S., Yin S., Rothman N. and Smith M. T., (2004): Hematotoxicity in Workers Exposed to Low Levels of Benzene. Science; 306(5702): 1774-1776.

Liu C. S., Tsai J. H., Ku S. W., (2000): Comparison between complete blood count and urinary 
metabolites after exposure to benzene. Mid Taiwan Med J, 5: 235 $-242$

Malomo S. O.,(2000): Toxicological implication of ceftriaxone administration in rats. Nig. J. Biochem.Mol. Biol; 15(1): 33-38.

Modjtahedi B. and Maibach H., (2008): In vivo percutaneous absorption of benzene in man: Forearm and palm. Food and Chemical Toxicology; 1171-1174.

Nazia U., Kumar B. S., Salar K. M., Madhuri A., Reddy V. D., (2012): In vitro and in vivo evaluation of toxic effect of benzene on lymphocytes and hepatocytes. The Internet Journal of Toxicology; ISSN: 1559-3916.

Nazia U., Salar B. M., Santhosh K., Aziz N., David M. A., Reddy V. D., (2008): Impact of organic solvents and environmental pollutants on the physiological function in petrol filling workers. IJERPH; 5(3): 139-146.

Paulo C. F., Éverton D., Camila B. Maria P. B., (2010): Determination of Benzene, Toluene and N-Hexane in Urine and Blood by Headspace Solid-Phase Microextration/GasChromatography for the Biomonitoring of Occupational Exposure. J. Braz. Chem. Soc.; 21(1): 119-126.

Perbellini L, Pasini F, Romani S, Princivalle A, Brugnone B., (2002): Analysis of benzene, toluene, ethylbenzene and m-xylene in biological samples from the general population. Journal of Chromatography B.; 778: 199-210.

Plappert U., Barthel E., Raddatz K., Seidel H. J., (1994): Early effects of benzene exposure in mice. Hematological versus genotoxic effect. Arch Toxicol: 46: 284-290.

Rinsky R. A., Young R. J., Smith A. B., (1981): Leukemia in benzene workers. Am J Ind Med; 2:217-45.

Rothman N., Li G. L., Dosemeci M., Bechtold W. E., Marti G. E., Wang Y. Z., Linet M., Xi L. Q., Lu W., Smith M. T., TitenkoHolland N., Zhang L. P., Blot W., Yin S. N., Hayes R. B., (1996): Hematotoxicity among Chinese workers heavily exposed to benzene. Am J Ind Med; 29: 236246.

Schimming F., Levseo K., Kohme C., (1999): Biomonitoring of benzene and toluene in human blood by headspace-solid-phase microextraction. Fresenius J Anal Chem.; 363:88 -91.

Simon N. R., Rekha S., Brian A. W., Wong V. A., Farris G. M., (1997): Immunotoxicological effects of benzene inhalation in mal Sprague Dawley rats. Toxicology; 119: 227237.

Snyder R. and Hedli C., (1996): An Overview of Benzene Metabolism. Environmental Health Perspectives; 104(6): 1165 - 1171.

Subrahmanyam V. Ross, D., Eastmond D. A., Smith M. T., (1991): Potential role of free radicals in benzene induced myelotoxicity and leukemia. Free Radic Biol med; 11(5): 495-515.

Townsend J. C., Ott M. G., Fishbeck W. A, (1978): Health eam finding among individuals occupationally exposed to benzene. J Occup Med; 20: 543-548.

Tsai S. P., Wen C. P., Weiss N. S., Wong O., McClellan W. A., Gibson R. L., (1983): Retrospective mortality and medical surveillance studies of workers in 
benzene areas of refineries. J Occup Med; 285-292.

Ward E., Hornung R., Morris J., Rinsky R., Wild D., Halperin W., Guthrie W., (1996): Risk of low red or white blood cell count related to estimated benzene exposure in a rural worker cohort (1940 - 1975). Am J Ind Med; 29: 247-257.

Yakubu M. T., Adesokan A. A. Akanji M. A., (2009): Biochemical changes in the Liver, Kidney and Serum of rat following chronic administration of cimetidine. African Journal of Biomedical
Research; 9: $213-218$

Yakubu M. T., Salau I. O., Muhammad N. O., (2003): Phosphatase activities in selected rat tissues following repeated administration of ranitidine. Nig. J. Biochem. \& Mol. Biol; 18(1): 2124.

Yardley J. A., Anderson D., Parke D. V., (1991): The toxicity of benzene and its metabolism and molecular pathology in human risk assessment. Br.J.Ind.Med; 48: 437444.

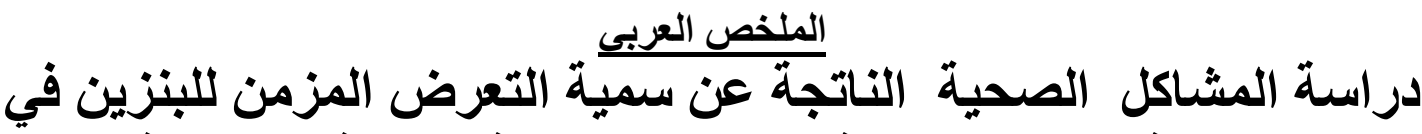 عمال تعبئة البنزين بمنطقة القصيم ــ المملكة العربية السعودية المنية}

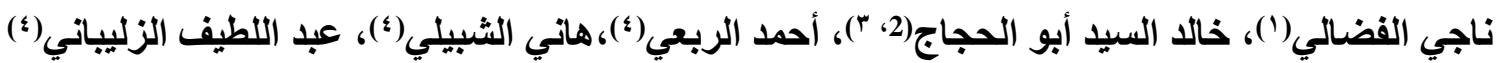

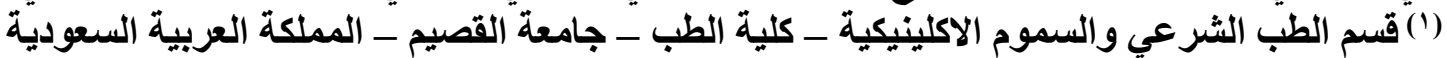

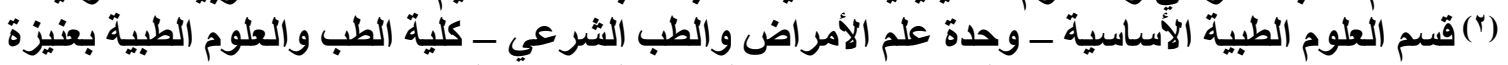

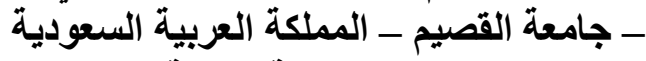

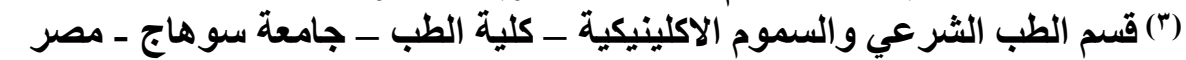

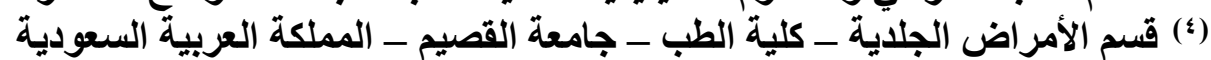

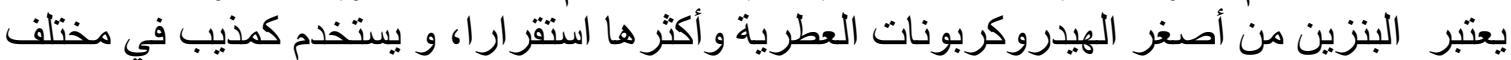

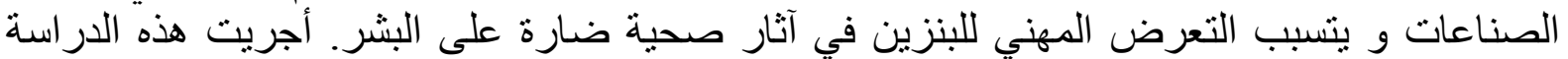

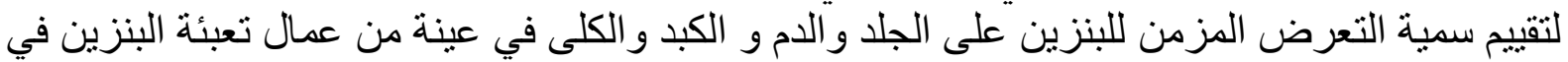

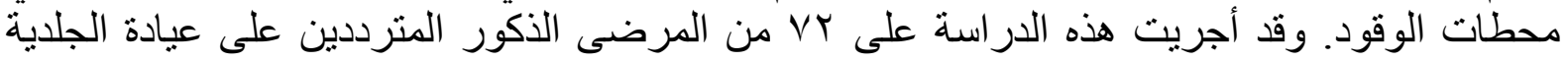

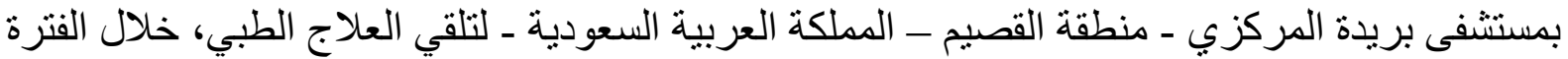

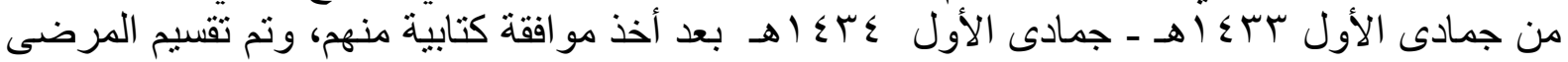

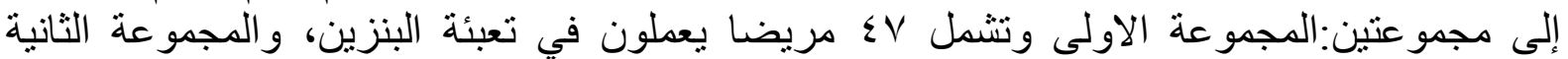
وتشمل هr مريضا يعملون مشرفين في محطات البنزين. وقد تم فحص المرضى المشاركين في البحث

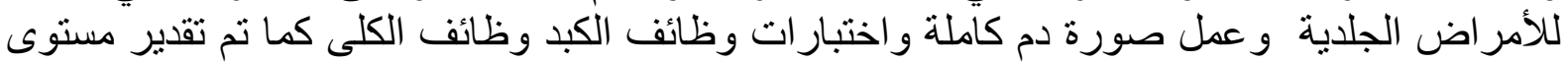

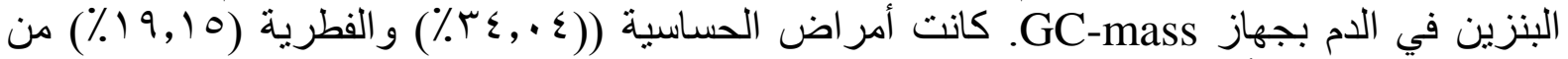

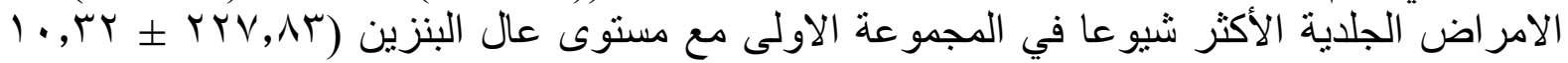

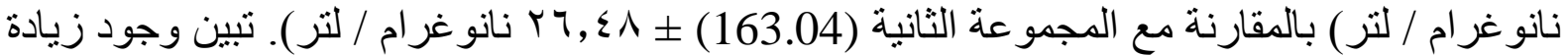

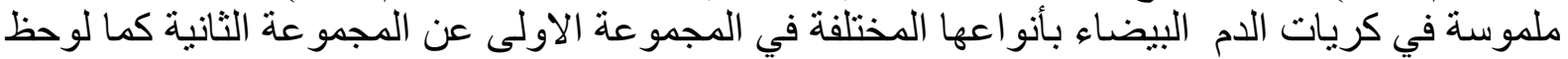

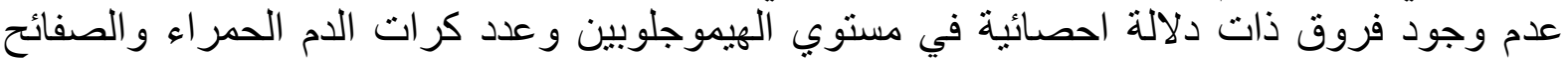

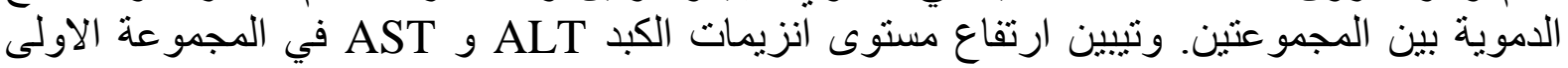

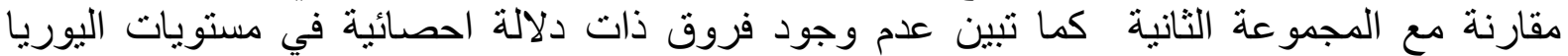

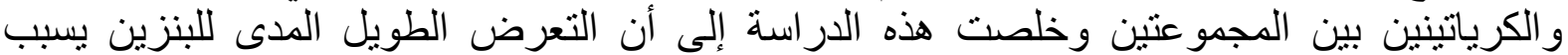

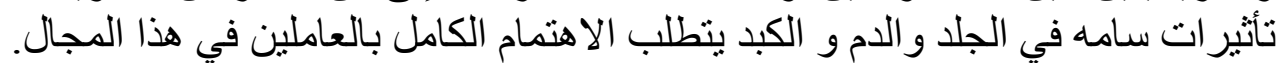

